\section{Central Ontario}

\section{Focus on Old Growth Forests}

The Central Ontario Section has organized three meetings over the past year and a half to investigate old growth forests (OGF). The first was a public forum on the Temagami wilderness issue, the second a field trip to Temagami, jointly arranged by the Central Ontario and Algonquin Sections and the Ontario Forestry Association and hosted by the Ontario Ministry of Natural Resources, while the third involved a tour to the Galloway Lake old growth pine area located in the Ranger Lake Crown Management Unit north of Sault Ste. Marie. The day-long tour to Galloway Lake was attended by 45 persons representing a broad crosssection of interests, including forest industry, researchers, communication experts, wildlife biologists and environmentalists.

The concept of OGF probably arose in the Pacific Northwest, particularly in Oregon and Washington. There, the term has been applied to intolerant to moderately tolerant, long-lived conifers, such as Douglas Fir, Sitka Spruce and others.

In Ontario the OGF issue has become one of the important elements of the Ministry of Natural Resources program of Sustainable Forestry. Within the province the OGF issue has focused on the beautiful, tall, long-lived white and red pine stands. These forests are known for their large trees, wide variation in tree sizes and spacing, accumulation of large size dead standing and fallen trees, multiple canopy layers, canopy gaps and understory patchiness, and decadence in the form of broken and deformed tops or bole, and root decay. Still other characteristics of OGF are as follows:

1. OGF is a descriptive term focusing on the later stages of development or succession of a forest type. The stage of interest, however, may not be the final stage of development. For example, white and red pine eventually will blow down in old age, leaving species that have developed under them, such as sugar maple, yellow birch, white cedar, white spruce, balsam fir, and other hardwoods and shrubs. There may be some white pine persisting in these stands, but it may be much reduced in quantity.

2. OGF as a concept can apply for all forest cover types (working groups). OGF is a valid concept, for example, for black spruce, jack pine, and sugar maple. Of course, the shade tolerance of various forest dominants varies from intolerant to very tolerant, and this will influence whether the species can replace itself and persist as a dominant in later stages of stand development. Only sugar maple has the ability to maintain itself indefinitely owing to its shade tolerance. As well, a species may be able to replace itself on some physiographic site types but not on others.

3. The composition and structure of OGF for a specific cover type varies according to the biogeoclimatic zone, and according to the physiographic, or ecological, site type. For example, OGF white and red pine occur on a wide range of sites, including shallow soil bedrock, deep heavy soils, deep coarse soils, and lakeside locations. The moderately shade tolerant white pine may be able to maintain itself in certain poor sites such as shallow to bedrock and course deposits, whereas on better soils with much competition it may convert in final stages to a hardwood with shade intolerant species predominating.

4. Many if not most white pine-red pine OGFs have arisen following wildfires. The studies of pine stand origin in Quetico by Bob Day in the late 70 s indicated a direct relationship between fire and how much pine was in a stand. If left undisturbed, and neither fire nor harvesting is permitted in such stands, it is thought that the old pine will be lost. However, studies by Peter Quinby sponsored by the Temagami Wilderness Association have concluded that pine can replace itself naturally if left alone. As noted above, this may be true for specific site types such as shallow soil, and for certain situations where natural wildfires have burned beneath but not killed the pine, allowing natural regeneration from seed. However, these regeneration patterns probably do not apply to all sites, and more research into natural regeneration processes and ecological influences is needed for the white and red pine OGF.
One of the main purposes for the tour was to obtain input on how the Galloway Lake forest should be harvested and regenerated. The objectives are to manage for wood production, to maintain old growth characteristics, and to renew white pine. Details of the prescription will include: (1) harvesting to leave some canopy, perhaps 25 white pine per ha, of the lower quality, potential high cull trees; (2) using product selective harvesting, shelterwood, or seed tree silvicultural methods; (3) harvesting to leave standing snags (dead trees); (4) careful logging methods, with a minimum of site disturbance; (5) use of minimum of skid trails and roads to reduce the impact on the site; $(6)$ delicate site preparation of the harvested areas with a small to medium size bulldozer to obtain enough plantable sites for ca. a $15 \mathrm{~m}$ spacing; (7) underplanting with white pine, and obtaining additional natural regeneration; (8) tending manually or chemically until pine is above the understory competition.

The values of OGF and the land on which it occurs - ecological economic and social - were a major theme of the discussions.

These values are numerous and include: biological diversity, wildlife and fisheries habitat, fibre and mineral values, recreation and tourism, water quality and quantity, scientific, genetic, educational, cultural, wilderness, spiritual, aesthetic, and heritage.

Much debate centered on the question of whether "old growth values"' can be maintained with logging. The loggers were concerned about the danger of falling snags in partial cut operations, and maintained that for safety these are required to be felled. It may be questioned whether the aesthetic,

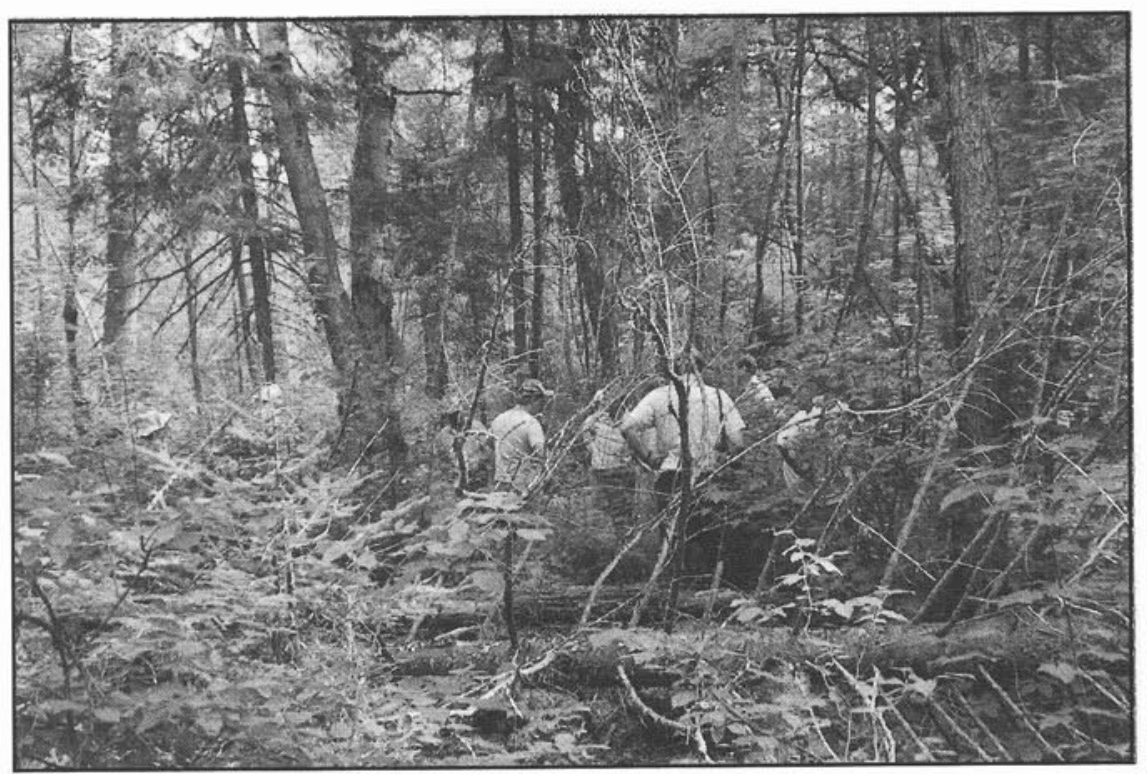

Participants in the Central Ontario Section tour of old growth ecosystems at Galloway Lake viewing pre-cut stand conditions (Photo: Heather MacDonald). 
spiritual, wilderness and heritage values can be maintained with a partial cut operation. Those who have seen partial cutting, and seen the forest develop after these operations, felt that the signs of logging and disturbance would become masked by vegetation regrowth and stump and slash decomposition, and that the forest would eventually look undisturbed after some years. Both even and uneven-aged forests that are selectively managed give an appearance to the untutored eye of pristine old growth, until one realizes that there are scattered stumps hidden beneath mossy mounds.

It was suggested that the OGF issue should be separated from the "wilderness" issue. OGF can accommodate a wide range of uses, including harvesting, and still maintain OGF values, whereas wilderness is a preservation concept which dedicates an area, that may or may not include old growth, to natural processes exclusive of any intervention by man, except for occassional passage by the wilderness traveller.

Only a brief mention was made of one of the most critical concepts - the idea that OGF should be part of an all-age forest that always contains a certain proportion of the OGF stage for all cover types. If OGF is dealt with in the context of forest management, then wilderness areas should first be set aside to accomodate this value. In a vision of the "forest for all values", there will probably be a need for dominant use areas, such as wilderness on the one extreme, and intensive tree farming on the other. The standard level of forestry, more extensive but still based on complete regeneration, would accomodate a range of values, i.e., "multiple-use'". Computer

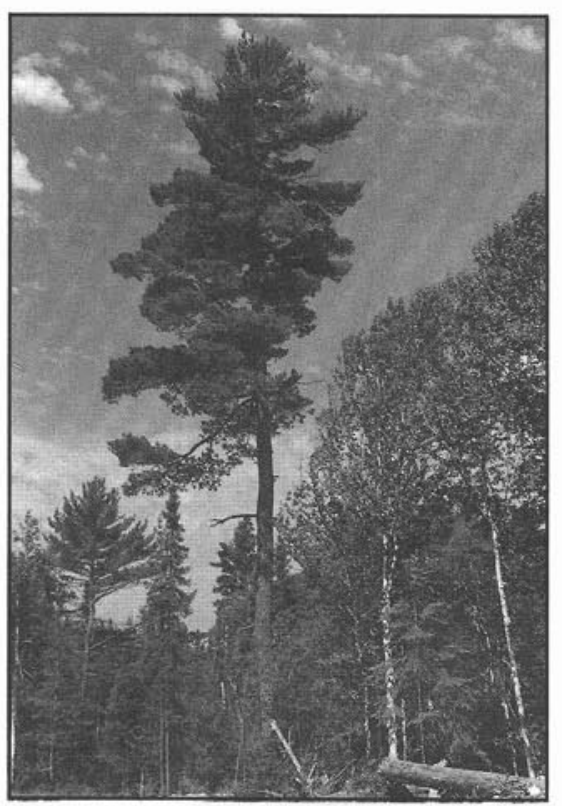

Part of the old growth ecosystem visited by participants on the Central Ontario Section tour to Galloway Lake. (Photo: Heather MacDonald). modelling and GIS will figure prominently in the development of a strategy of forest land use with various options and scenarios.

The field tour was a fine example of public participation, open discussion, freeexpression of ideas, minimal confrontation and rancour, and an attempt to honestly come to grips with the conflicting uses and values for forests and forest land. The "public" in this case was almost all from the forestry community, but it may be hoped and anticipated that the general public can be informed and brought into these discussions. The Central Ontario Section intends to play an active role in this issue in its public awareness program, and will contribute to the development of a conservation strategy for Old Growth Forests.

John Jeglum, Vice-Chairman

Editor's Note: The decision by the Ministry of Natural Resources to allow logging in the Galloway Lake area has been criticized by environmentalists. The provincial government announced in May that major old growth forests in the province would be protected pending the development of an old growth strategy. Logging in the Galloway Lake area was allowed to continue because there was a logging road in the area and a small section had been cut.

\section{Newfoundland}

\section{Mini-Forums}

During the winter three Mini-Forums were held, two in St. John's and one in Corner Brook. Joanne MacDonald gave the first one in St. John's in January on the subject of "Dormancy Induction and Development in Containerized Seedlings: Can It Be Manipulated?" The second, also in St. John's, was presented by Ian Thompson on the subject of "Integrated Resource Management." At the Corner Brook Mini-Forum in late February Bill Buggie talked about the "Roddickton Commercial Thinning Trials."

\section{Academic Awards}

On April 15, 1991, Tim Moulton presented Faron Lidstone of Botwood, a Forest Resources Technology II student at the Fisher Institute of Technology with the Frank Gogos Award for Excellence in Forest Management. Faron received a certificate and a cheque for $\$ 200.00$ from the Section.

Also this spring Carl Whiffen of Southern Harbour, a Forestry student at Memorial University, was presented with the Finn Frost Award. Carl who will be working with Joanne MacDonald this summer, will be moving on to the Forestry program at the University of New Brunswick in the fall.

\section{Tree of Life Award}

The 1990 recipient of the Tree of Life Award for the Newfoundland Section is Wayne Brown. Wayne has yet to actually receive the award. The presentation will take place at the next Mini-Forum in Corner Brook.

\section{The Executive}

Chairman, Bill Alexander; Past-Chairman, Charles John; Vice-Chairman, Denes Bajzak; Secretary Treasurer, George Veitch; Councillor, Lorne West; Councillor, Tim Moulton; Councillor, Basil English.

\section{From Section Newsletter}

\section{Rocky Mountain}

\section{Rocky Mountain Section Technical Session - Grande Prairie}

The Rocky Mountain Section convened its fourth and final technical session for the 1990/91 year, in Grande Prairie on May 10, 1991. It was held in conjunction with the Northern Alberta Forestry Equipment Show. About 75 members attended the session.

The theme of the technical session was protection of the forest environment. Today both government and industry foresters are challenged to develop innovative ways to conduct harvest operations and to develop clear operating guidelines that ensure the objectives of environmental protection are met.

Mr. Gary Dahlgren, Sales Forester for the Flathead National Forest at Kalispell, Montana, spoke about the United States Forest Service's environmental and integrated use considerations in timber harvesting.

Gary described several legislative statutes that are pertinent to the USFS's management mandate including the following: The Creation Act, 1891 (which created the Forestry Service); The National Environment Policy Act, 1969 (which ensures integrated management and decision making and includes watchdog groups that can appeal the decision process); The Endangered Species Act, 1973 (which protects grizzly bears, grey wolves, and bald eagles within the forest); and the National Forest Management Act, 1976 (which establishes the allowable cut of the forests).

This legislation has tremendous impact upon the way the Forests are managed in the United States. For example, in the Flathead Forest this legislation lead to the development of a Forest Management Plan which enabled the establishment of the allowable sale quantity. That level of cut was appealed by three local interest groups who submitted 19 allegations primarily under the Endangered Species Act. Because of the appeal process the Forest has only been able to sell 60 million bdft of its allowable 100 million in recent times.

Old growth timber is a big concern in the United States Forest Service and for the public. Gary stated that even after considerable harvest, there is still about $25 \%$ of the Flathead Forest still in the "Old Growth" category. 
In response to public concerns about forest management, the Forest has developed a public participation program to teach people about the importance of the forest from a biological and economic point of view, called, "Family Forestry Expo".

Mr. Dave Lawrie, an engineering forester with the B.C. Ministry of Forests, spoke about some interim harvesting guidelines being developed for the interior of British Columbia.

In the past few years, soil disturbance has been recognized as a serious threat to forest productivity. The coastal regions use cable or grapple yarder systems which reduces soil damage. However, in the interior regions of B.C., log skidding is primarily acheived with ground skidding systems. It has been estimated that $35-45 \%$ of the ground is damaged by skidding in the interior regions and that is why these guidelines were developed. The objective of the guidelines is to prevent unnecessary disturbance that will cause a loss of site productivity.

The guidelines are based upon a site sensitivity rating that is based upon a field examination of the site. Measurements include soils, slope and moisture regimes. These factors are related to a key in the manual that indicates the percentage of the total area of the cutblock that may be disturbed. In some cases it has lead to a change in skidding systems from conventional ground skidding to cable yarding. Initial assessments show that this system will effectively reduce ground disturbance by up to $50 \%$.

Mr. Steve Ferdinand, manager of the Woods Operations Section of the Timber Management Branch of the Alberta Forest service, addressed the audience about the Alberta Timber Harvest Planning and Operating Ground Rules. Steve was responsible for the current edition of the ground rules and is currently revising them to meet new challenges in the industry.

The Alberta Timber Harvest Planning and Operating Ground Rules (known as the "ground rules") have been in place for about 30 years, he said. They are a collection of rules and guidelines that apply to the planning and conduct of timber harvesting on publically owned permanent forest lands. The purpose is to facilitate the harvest of timber: in a manner consistent with sound forest management and multiple use objectives; and with minimal negative short and long term impacts on the forest environment.

Mr. Mark Starnes, Woods Product Manager, of Proctor and Gamble's Alberta operations, spoke about forest management and its relationship with the environment and about the public's perception of the forest industry.

The public has different expectations from the forest industry than they do from other industries working in the environment, Mark said. They expect the forest industry to operate in harmony with the environment while others like agriculture are under less pressure to do so. He said, society essentially accepts these activities as necessary for their lifestyle and the associated environmental impacts.

The public is telling us that a condition of our existence is to operate in harmony with the environment. The tolerance for any negative impact is very low. Many do not see our industry as a major factor in maintaining its way of life. They have very little data upon which to make decisions and draw conclusions. Without appropriate data they are forced to go with intuition, emotions and instincts. Any perceived threat to the forest is viewed as unacceptable and in that context the forest industry is seen to be expendable. It is out of a reverence for the forest that this aparent double standard is applied.

\section{Upcoming Event}

Date : January 17-18, 1992. CIF Technical Session.

Theme : Environmental/Political Influences on Sustainable Forest Development

Program : Speakers, question and answer, workshops. Held jointly with the ARPFA.

Location : Hinton, Alberta.

Gordon W. Brown

\section{Ottawa Valley}

\section{Annual Report by Section Chair 1990-91}

A certain amount of frustration is associated with chairing the Ottawa Valley Section of CIF/IFC. On the one hand, our Section is well-situated close to the action in national forestry policy affairs, with the headquarters of Forestry Canada, and the offices of a wide variety of organizations such as Canadian Forestry Association, Canadian Lumbermen's Association, Canadian Institute of Treated Wood, Canadian Nature Federation, and Canadian Wildlife Federation in our midst, not to mention the Ottawa Valley's traditional and continuing association with the lumber and more recently the pulp and paper industries. Many of the key people in these organizations are amongst our members. Visiting international delegations pass through the national capital regularly. Thus we should be well placed to have a say in forestry matters at the national policy level, and to contact and communicate with key people nationally and internationally.

On the other hand, we run into continual difficulties in making that vision a reality. Section Council comes up with some interesting program ideas, but often has problems lining up interesting speakers at the right time. Then too, encouraging people to come out to meetings, or to take on some of the policy issues from a CIF perspective, is a continual struggle. Part of the problem lies in that those members who are not retired are all busy with the day-to-day running of the national forestry scene. It is always rather difficult to find time to step back and look at the issues from a personal or CIF perspective, when you hardly have time to keep up with all your employer's demands. Some of us are perhaps too close to the action.

However, one of our strengths as a Section is our retired members, many of whom have been in key positions during their careers, have a good idea of how things work at the national level, and now have a bit more time to become involved actively in CIF affairs. These members are the backbone of our Section meetings, and serve as inspiration, encouragement and challenge to our younger members. I would hope that the incoming Council, which I suspect will have a number of new, younger faces, will try to combine the enthusiasm and ideas of the young with the 'wisdom of the ages' amongst our Section membership.

One project we undertook this year gave Council much encouragement - the program questionnaire which was circulated last fall. Twenty-two members responded by sending in completed questionnaires. This is not a high rate of return, but in general, the responses were very positive. Members felt we were on the right track with what we were doing in program activities. Though there were some differences of opinion, midweek lunch meetings were favoured. Responses suggest that a variety of formats including scientific presentations, panels and field trips would please most members. Remarkably few people thought we were charging too much. (One person was even prepared to pay "anything" in order to participate.) Particularly encouraging was the number of respondents who said they were willing to devote time to preparing position papers or resolutions, or better still, were willing to make a presentation to a Section meeting or take part in a panel. Unfortunately, not all of those volunteers included their names. The language issue was broached, and though all respondents preferred English, many thought it worthwhile to try the occasional Section meeting in French. Council has taken some of these findings into consideration in the past months. I hope that the incoming Council will continue to do so, particularly in following up on those volunteers.

Six Section meetings were held during the year, with a variety of topics and a variety of speakers. All were interesting and enjoyable. With the exception of the annual meeting, all were midweek lunchtime meetings. I regret that due to work commitments, I was only able to attend half of those meetings. Henry Walthert's report as Program chair will provide more details on 
individual meetings. Section Council met three times during the year.

Once again, Ottawa Valley Section participated in the Regional Science Fair, by presenting an award to the project considered to have most merit from a forestry perspective. The judging this year was undertaken by Claude Léger, Claude Turmel and Ole Hendrickson.

For some of our members, the national annual meeting in Fredericton, New Brunswick last year was somewhat overshadowed by the IUFRO Congress in Montreal which immediately preceded it. Nevertheless, there was a good representation of Ottawa Valley Section members at the Fredericton meeting.

Presentations of Tree of Life Awards were made by the Section to Les Carlson and Ewan Caldwell. These awards are made by Sections 'to recognize individuals who have made superior, dedicated or particularly effective contributions to sustainable resource management, forest renewal or sustained yield integrated management of the forest and its intrinsic resources.' This year, the Section has also nominated two worthy members for Fellow membership in CIF/IFC,

\section{Jim Richardson}

\section{Algonquin}

\section{The Gillies Grove}

In early January a brief was prepared stating the Section's position on the "Gillies Grove"' controversy in Arnprior. Most of this area of approximately 25 hectares (65 acres) of "old growth" white pine is within the Town of Arnprior. The property originally belonged to the Gillies family, well known in the logging history of the Ottawa Valley. For many years it has been open to the public and has been used as a natural area park by the local residents. A few years ago it was acquired by the Galilee Mission Centre of the Oblate Fathers who own adjacent property where their Mission is located. The area is currently zoned for open space and institutional use and the present owners want it re-zoned as residential so that a housing project can be developed on it and the proceeds used to finance the expansion of their Mission Centre. A citizens' group, the "'Save the Grove Committee", was formed to fight the housing project and preserve the natural forest area. This committee invited the Algonquin Section of the C.I.F. to inspect the property and comment on its value as a forest property.

Following inspection of the property, the Section prepared a brief recommending that the management objective for the Grove be the provision of a healthy forest for the nonconsumptive use of regional residents. Primary products will be recreation, aesthetics and education. Natural succession will eventually provide an uneven aged hardwood forest and no intervention will be required for renewal. The Section considers that residential development of the grove would be a hazard to the area not developed because of the likelihood of widespread windthrow following disturbance and because residential development means landscapings, drainage ditches and pipeline construction. The disturbances associated with residential development would alter drainage patterns of the area and the resulting stress would likely kill the older trees.

Copies of the brief can be obtained from the Algonquin Section.

On April 24, 1991 the Algonquin Section along with the Ottawa Valley Section hosted a public forum/information session in Arnprior to look at the land use issue of the Gillies Grove. The program featured four speakers: Ole Hendrickson from Forestry Canada in Ottawa, Stan Gitterman, Housing Development Planner from Rockcliffe Village, Ottawa, Mike Murphy of the Ottawa Field Naturalists Club, and Jack Wright, University of Ottawa Recreation Specialist.

\section{A Green Night}

In keeping with a well-established annual tradition of "International Nights" wherein customs and food of various parts of the world are featured, the Algonquin Section this year honoured Ireland at a special Section meeting.

"A Green Night" was held at the Petawawa National Forestry Institute on January 18, 1991. 69 members and guests enjoyed a fine dinner of traditional Irish food featuring; Irish Soda Bread, Emerald Salad, Mock Dublin Bay Prawn (shrimp cocktail), Guinness Roast Beef, Roast Potatoes, Buttered Turnip, Braised Onions and Carrots, Bakewell Tarts and Whipped Cream, Sherry Trifle, and finished off with Irish Coffee.

After dinner entertainment began with a sing-song of Irish tunes led by Larry $\left(\mathrm{O}^{\prime}\right)$ Scales.

Guest speaker was Dave Brand who presented highlights of Canada's Green Plan and the government processes the program went through in the course of development. $\mathrm{He}$ then outlined the forestry aspects of the Plan, as they were available to the public at that time.

\section{Barry's Bay Public Forum}

On February 8, 1991 the Section hosted a public forum in Barry's Bay on the topic "The Utilization of Low Quality Wood in Renfrew County"'. The program featured four speakers; Professor John J. Balatincez of the Faculty of Forestry, University of Toronto, Larry Powell from the Ontario Ministry of Natural Resources in Pembroke, Jack Alexander, Coordinator of Non-utility Generation, Ontario Hydro, Belleville, and Jeff Monty from the Petawawa National Forestry Institute and Section Chairperson.
Professor Balatincez spoke of the value of the forest industry to Canada. Larry Powell described the situation in the local forests including how much low quality wood is available for harvest. John Alexander spoke about the possibility of Ontario Hydro buying electricity from a cogeneration plant. Jeff Monty gave a slide presentation that featured facilities in Canada currently using wood as a source of heat and energy.

\section{Annual Meeting}

The Section annual meeting was held July 4, 1991 at the Coulonge Golf and Country Club, Fort Coulonge, Quebec. The meeting was preceded by a visit to the historic and scenic "Les Grandes Chutes" on the nearby Coulonge River. Guest speaker for the evening was Chris Lee, CIF/IFC Executive Director.

Chairperson Jeff Monty reviewed the Section activities of the past year (as listed above) plus the joint meeting with the Central Ontario Section in Temagami in October and the awards night meeting at Algonquin College in November. Jeff referred to the 1990 annual meeting when it was decided that the Section Program for the next year would concentrate on securing pro-forestry support from the general public. This was to be accomplished by having the Section sponsor public forums on various forest management issues, and setting up a speaker's bureau. He concluded, with unanimous agreement, that the Section had just completed a successful year and most of the objectives had been met.

The following slate of officers were nominated by the nominating committee and subsequently elected by acclimation: Director, Jeff Monty; Chairperson, Larry Scales; Vice-Chairperson, Margaret Penner; Councillors, Fred Pinto, Hugh Schooley, Don Honeyborne, Mike Weber.

\section{Don Honeyborne, R.P.F.}

\section{Vancouver Island}

\section{Retiring Chairperson's Report - 1990-91}

The Vancouver Section of the Canadian Institute of Forestry has had a lively and busy year. The central spirit of the Section was given a massive jump start this year through the tireless efforts of Vice Chairperson/Program Chairperson Bob Craig who did a masterful job on the program. Attendance at this year's dinner meetings was regular and at a high level. We purposely targeted an introspective, no-press, format so that members would feel free to ask tough questions and critically evaluate opinions being expressed. We had several good discussions and many weak points on approaches to current forest policy were laid 
bare. It remains to be seen if any of the "messages" result in any actions.

Communications among the section was well handled this year by interesting and informative Updates by Brenda Hanson in Public Relations. Brenda also maintained linkages between the section and the National Forest Week Committee, although the latter did appear in some disarray at times. Our Section Secretary, Chris Chanway, made sure that all meeting notices were sent out promptly. He was aided in this task by mailing labels that were kept up to date by Grant Thompson, our Membership person. Madame Treasurer, Susan Craven, watched our expenditures with eagle eye and sharp pencil.

Our Past Chairperson, Jock Dobie, continued to work solidly for the Section with follow-up discussions to the Forestry Commission Report. He has also contributed to the start up of HAMPCO 92. Our thanks also to Jock for tenaciously seeking a permit for a Casino Night as a way to raise money for the section. In the long run they deemed us ineligible. John Clarke worked closely with Student Reps Shawn Hedges (UBC) and Don Tucker (BCIT) to revive an INTERACT Program as a way of encouraging participation by the younger generation. This effort will be sustained and hopefully brought to fruition in 1991/92. Shawn also worked hard to make this year's Ring Ceremony a great success. We shared a novel experience when three east German Horn players, who just happened to be on their first tour to the West, were brought along to the function by Jack Toovey. The Ring Ceremony was ushered in and closed by traditional East German horn calls.

Many Section members have willingly contributed their time to developing the plans for HAMPCO 92, the Annual Meeting of the Canadian Institute of Forestry. I urge all members to become involved in any way they can. A speciai tribute to our incoming Chairman Bob for reminding us about the National scope of the Canadian Institute of Forestry. We are part of a national organization. We need to ensure our local strength through participation and recruitment of new members, especially the younger set. I hope as many of you as possible will be able to attend the National Meeting in Toronto in September so you can learn about National concerns in forestry as well.

Thank you all for such great support in 1990/91.

\section{John McLean}

\section{Program 1991-92}

November 17, Strictly for the Birds!

December 17, New Forestry? What's so New?

January 21, How Do We Manage the Media?

February 18, Native Forestry: A Reality March 17, April 21, U.B.C. Ring Ceremony What's Really Happening in Integrated Resource Management?

The Vancouver Section Award of a pair of binoculars was awarded this year to James Scott, the top Renewable Resources graduate in the BCIT School of Engineering Technology. Here we see Program Head of Forestry Mr. Don Campbell ( $R$ ) receiving the binoculars on James Scott's behalf from Vancouver Section Chairman John McLean (L).

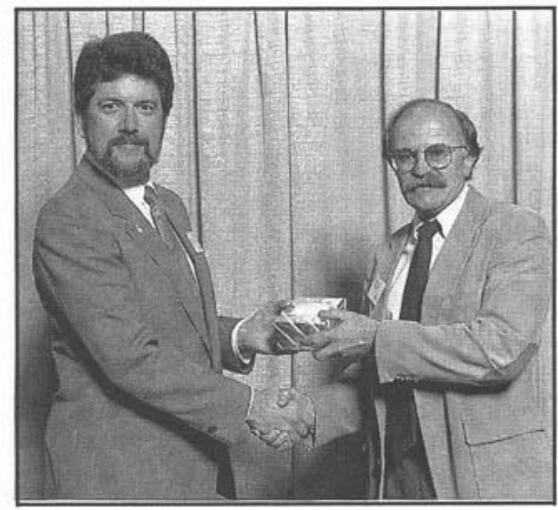

\section{University News/Nouvelles des universités}

\section{Toronto}

\section{Retirements}

Miss Pat Balme retired at the end of June after working as the secretary of the Faculty of Forestry for 41 years. At her retirement party, Dean Carrow announced that Pat had seen 80 percent of the Faculty's graduates through their studies. She counts many friends and admirers among them all.

Dr. Jim Bendell, a professor in wildlife biology, also retired at the end of June. Dr. Bendell came to the Faculty in 1972 as a Kortright Professor of Forest Wildlife Management. He was also an Associate Professor at the Institute of Environmental Studies. Dr. Bendell is considered a world expert on grouse.

\section{Recent Appointments}

Dr. David G. Puttock has accepted the position of Assistant Professor, Forest Management, as of July. He is responsible for undergraduate teaching and graduate supervision in the areas of timber harvesting, business administration, and land management and natural resource planning. Dr. Puttock successfully defended his Ph.D. thesis, entitled A Microeconomic Model of the Hardwood Lumber Manufacturing Industry in Ontario, at the University of Guelph last January.

Dr. Paul A. Cooper has been appointed Assistant Professor, Wood Science. He is responsible for teaching wood science and forest management courses, as well as coordinating the 16-month Professional Education Year that undergraduate students may participate in between their second and third years.

Dr. W. Andrew Kenney is now an Assistant Professor. He will be teaching undergraduate courses in contemporary issues in forestry and forestry in development, as well as conducting research for the Ontario Ministry of Energy on the demonstration and testing of willow and poplar biomass plantations in farm settings.
Ms. Fleur Macqueen joined the Faculty of Forestry in June as the Community Relations Coordinator, a new position with the Faculty. She will be working on high school recruitment, special events planning and media relations. Previously she was the assistant editor of Canadian Datasystems, a magazine for information systems and data processing professionals.

Dr. J. Rod Carrow has been re-appointed as the Dean of Forestry for a second term, from July 1, 1991 to June 30, 1994.

Mr. Ed Bevilacqua has joined the Faculty's academic staff as Tutor, Forest Management. $\mathrm{He}$ is teaching undergraduate courses in natural resource information systems, forest mensuration, forest measurement techniques and the use of recently acquired Geographic Information System.

Dr. Jennifer Juzwik of the U.S. Forest Service has joined the Faculty as an Adjunct Professor of Forest Nursery Hygiene and Culture. Dr. Juzwik is serving on graduate student committees and doing cooperative research with faculty members on forest health.

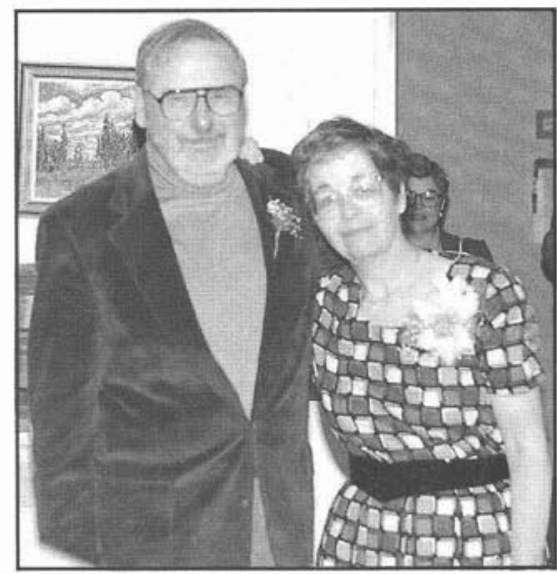

Dr. Jim Bendell and Miss Pat Balme both retired at the end of June. Dr. Bendell had worked for the Faculty of Forestry for 19 years and Miss Balme for 41 ! 